\title{
Inferior Vena Cava Leiomyosarcoma
}

National Cancer Institute

\section{Source}

National Cancer Institute. Inferior Vena Cava Leiomyosarcoma. NCI Thesaurus. Code C5372.

An aggressive malignant smooth muscle neoplasm, arising from the inferior vena cava.

It is characterized by a proliferation of neoplastic spindle cells. 